\title{
Comparative simulation study between $n$ - type and p- type Silicon Solar Cells and the variation of efficiency of $n$ - type Solar Cell by the application of passivation layer with different thickness using AFORS HET and PC1D.
}

\author{
U.Gangopadhyay, S. Roy, S.Garain, S. Jana, S.Das \\ Meghnad Saha Institute of Technology (TIG), Nazirabad, Kolkata-700107.
}

\begin{abstract}
In this paper, comparative study of $p$ type and $n$ type solar cells are described using two popular solar cell analyzing software AFORS HET and PCID. We use SiN $N_{x}$ layer as Antireflection Coating and a passivated layer $\mathrm{Al}_{2} \mathrm{O}_{3}$. The variation of reflection, absorption, I-V characteristics, and internal and external quantum efficiency have been done by changing the thickness of passivated layer and ARC layer, and front and back surface recombination velocities. The same analysis is taken by imposing surface charge at front of n-type solar Cell and we get 20.13\%-20.15\% conversion efficiency.
\end{abstract}

Keywords: - ARC coating, Surface recombination velocity, Passivation layer, Surface charge, AFORS HET, $P C 1 D$

\section{INTRODUCTION}

Solar energy is an abundant source of green energy .It plays a crucial role due to increasing price of fossil fuel and acute shortage of them which also leads to global warming. At present more than $85 \%$ of the industrial solar cells are fabricated based on $\mathrm{p}$ type silicon material. The $\mathrm{n}$-type solar cell is one of the interesting technological solution basically due to its lower recombination velocity, tolerance of higher temperature, higher carrier lifetime [1]. It offers high stabilized cell efficiencies because they do not suffer from light induced degradation(LID) caused by the simultaneous presence of boron and oxygen in the wafers[2], a phenomenon that in standard p-type silicon solar cells leads to a reduction of the module power output by usually two to three percent within the first weeks of installation. Second, $\mathrm{n}$-type $\mathrm{Si}$ wafers are less sensitive to impurities that are usually present in silicon feedstock; consequently, fewer efforts have to be made to obtain $\mathrm{n}$-type $\mathrm{Si}$ wafers with a high electronic quality.

On the other hand, one of the important reasons for decreasing efficiency for solar cell is the reflection of light from the air/silicon interface. This reflection reduces the external quantum efficiency. So an adequate layer of antireflection coating (ARC) can be used to match the optical impedance and reduce the reflection. $\mathrm{SiN}_{\mathrm{x}}$ is most popular and commercially available ARC [3]. But $\mathrm{SiN}_{\mathrm{x}}$ layer induces a positive surface charge density of the order of $10^{12} \mathrm{~cm}^{-2}[2,4]$, so it has a detrimental effect on the efficiency of $\mathrm{p}+/ \mathrm{n}$ or $\mathrm{p}^{+} / \mathrm{n} / \mathrm{n}^{+} \mathrm{c}$-Si solar cell. To achieve a solar cell with higher efficiency, a highly effective surface passivation of the cell both at front and rear, should be required. Lower recombination velocity is achieved by using this passivation layer. $\mathrm{Al}_{2} \mathrm{O}_{3}$ acts as

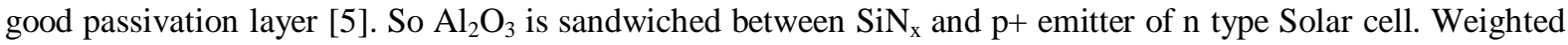
reflectance for $\mathrm{Al}_{2} \mathrm{O}_{3} / \mathrm{SiN}_{\mathrm{x}} \mathrm{ARC}$ stack is $10.50 \%$ [6] and it reduces the front surface recombination velocity upto10 $\mathrm{cm} / \mathrm{s}[7] . \mathrm{Al}_{2} \mathrm{O}_{3}$ is a wide band gap dielectric $(8.8 \mathrm{eV})$ with dielectric constant around 9 [8].

The aim of this study is to analysis the performance of the $\mathrm{n}$-type solar cell and represents a comparison with p- type Solar cell using PC1D and AFORS HET. We also study the effect of positive and negative surface charges on the front surface of the n-type Solar Cell. To achieve maximum efficiency of n-type solar cell, we optimized the passivated layer thickness and the recombination velocity. This simulation is done by PC1D due to some difficulties facing during simulation with AFORS HET to increase the performance of solar cell.

\section{SIMULATION AND RESULTS}

The structure for the modeling of crystalline silicon solar cells used in this paper as shown in Fig.1. The background doping density of n-type base is $10^{16} \mathrm{~cm}^{-3}$, and its thickness is $200 \mu \mathrm{m}$. The $\mathrm{p}+$ emitter has a peak density of $10^{19} \mathrm{~cm}^{-3}$ at the front surface, with the sheet resistance of $\sim 100 \Omega / \mathrm{cm}^{2}$ and the emitter junction depth of $0.5 \mu \mathrm{m}$. 


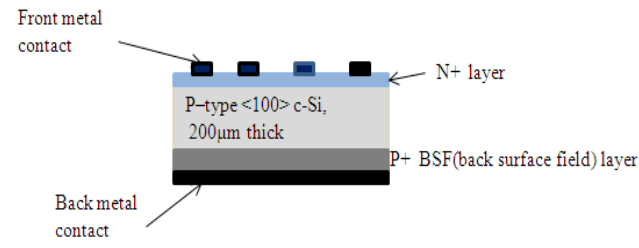

(a)

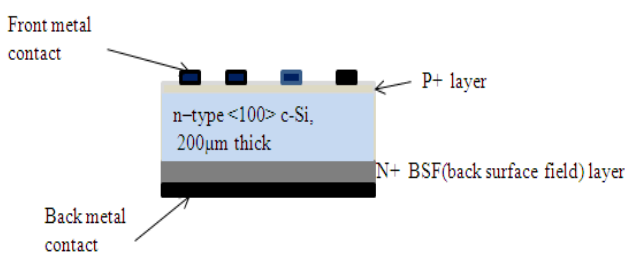

(b)

Fig 1: schematic diagram of simulated c-Si solar cell structure (a) $n^{+} \mathrm{pp}^{+}$and (b) $\mathrm{p}^{+} \mathrm{nn}^{+}$

The rear diffusion has a peak intensity of $10^{19} \mathrm{~cm}^{-3}$ with junction depth and sheet resistance. The electron and hole lifetime parameters were set at $100 \mu \mathrm{s}$, for both n-type and p-type, the corresponding diffusion length of $400 \mu \mathrm{m}$ and $139 \mu \mathrm{m}$ respectively, with the background doping density of $1 \times 10^{16} \mathrm{~cm}^{-3}$ at the temperature of $300 \mathrm{~K}$. The front and back surface recombination velocities (FSRV) are about $1 \times 10^{6} \mathrm{~cm} / \mathrm{s}$. The standard AM1.5G was chosen as the illumination source, corresponding to an intensity of $0.1 \mathrm{~W} / \mathrm{cm}^{2}$ at $25^{\circ} \mathrm{C}$. In addition, the texture depths of the front and rear surface were both $0.4 \mu \mathrm{m}$, some important solar parameters of crystalline silicon solar cells are used in the simulations were shown in Table-1, and all of the other parameters were the default values in PC1D. Here both p- type and n-type cells are simulated and they both show more or less $12 \%$ efficiency.

Table 1: Variation of different parameters of $\mathrm{N}$ type Solar Cell

\begin{tabular}{|c|c|c|c|}
\hline \multicolumn{2}{|l|}{ p-n-n+ type Solar Cell } & \multicolumn{2}{|l|}{ n-p-p+ type Solar Cell } \\
\hline Varying Parameters & Value & Varying Parameters & Value \\
\hline $\begin{array}{l}\text { Front and back side doping } \\
\text { concentration }\end{array}$ & $1 \mathrm{E} 19$ & $\begin{array}{l}\text { Front and back side doping } \\
\text { concentration }\end{array}$ & $1 \mathrm{E} 19$ \\
\hline $\begin{array}{l}\text { Front side }(p+) \text { doping junction } \\
\text { depth }\end{array}$ & $0.4 \mathrm{um}$ & $\begin{array}{l}\text { Front side }(n+) \quad \text { doping } \\
\text { junction depth }\end{array}$ & $0.4 \mathrm{um}$ \\
\hline $\begin{array}{l}\text { Rear side }(n+) \text { doping junction } \\
\text { depth }\end{array}$ & $0.8 \mathrm{um}$ & $\begin{array}{l}\text { Rear side }(\mathrm{p}+) \text { doping } \\
\text { junction depth }\end{array}$ & $0.8 \mathrm{um}$ \\
\hline ARC coating & No & ARC coating & No \\
\hline $\begin{array}{l}\text { Front and rear Side carrier } \\
\text { recombination Velocity }\end{array}$ & $1 \mathrm{E} 6 \mathrm{~cm} / \mathrm{s}$ & $\begin{array}{l}\text { Front and rear Side carrier } \\
\text { recombination Velocity }\end{array}$ & $1 \mathrm{E} 6 \mathrm{~cm} / \mathrm{s}$ \\
\hline Carrier life time & $0.001 \mathrm{~s}$ & Carrier life time & $0.001 \mathrm{~s}$ \\
\hline $\begin{array}{l}\text { AFORS HET } \quad \text { simulation } \\
\mathrm{V}_{\mathrm{oc}}=620.7 \mathrm{mV}, \mathrm{J}_{\mathrm{sc}}=23.94 \mathrm{~mA} / \mathrm{cm}^{2}, \\
\eta=12.33 \%\end{array}$ & $\begin{array}{l}\text { esult : } \\
\mathrm{FF}=83 \% \text {, }\end{array}$ & $\begin{array}{l}\text { AFORS HET } \begin{array}{r}\text { simulation } \\
\mathrm{V}_{\mathrm{oc}}=672 \mathrm{mV}, \mathrm{J}_{\mathrm{sc}}=23.26 \mathrm{~mA} / \mathrm{cm} \\
\eta=12.1 \%\end{array}\end{array}$ & $\begin{array}{c}\text { result } \\
2, \mathrm{FF}=83.82 \% \text {, }\end{array}$ \\
\hline $\begin{array}{l}\text { PC1D simulation result: } \\
\mathrm{V}_{\mathrm{oc}}=0.600 \mathrm{mV}, \quad \mathrm{J}_{\mathrm{sc}}=24.78 \mathrm{~mA} / \mathrm{cm}^{2}, \\
\eta=12.97 \%\end{array}$ & & $\begin{array}{l}\text { PC1D simulation result: } \\
\mathrm{V}_{\mathrm{oc}}=0.595 \mathrm{mV}, \mathrm{J}_{\mathrm{sc}}=23.14 \mathrm{~mA} / \mathrm{c} \\
\eta=12.2 \%\end{array}$ & \\
\hline
\end{tabular}

\section{II.I AFORS HET SIMULATION GRAPHS FOR N TYPE SOLAR CELL}

The reflection and transmission curve of the Solar cell at the particular condition using AFORS HET is shown in table 1. It has been observed that the Solar cell shows $40 \%$ reflectance, so the residual of the light should be absorbed into the cell. 


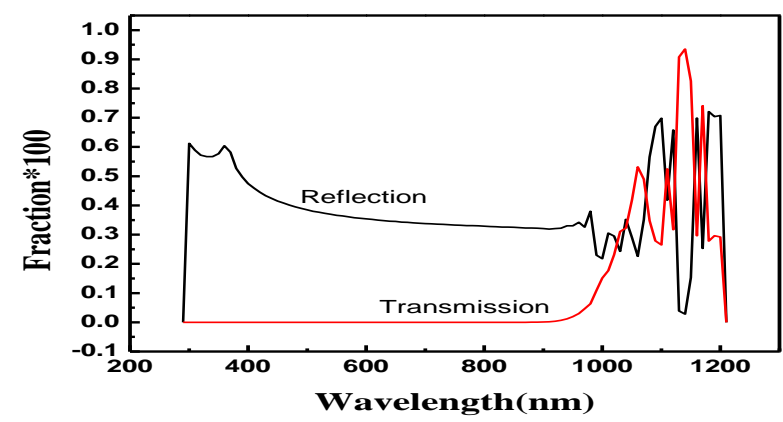

Fig.2: Reflectance and Transmittance curve for different wavelengths

Neglecting the scattering and dispersion phenomenon the summation of reflection, absorption, and transmission will be $100 \%$. In fig. 2 due to zero transmissions the residual light should be absorbed into the bulk material of the cell. Fig 3 shows the absorption with wavelength.

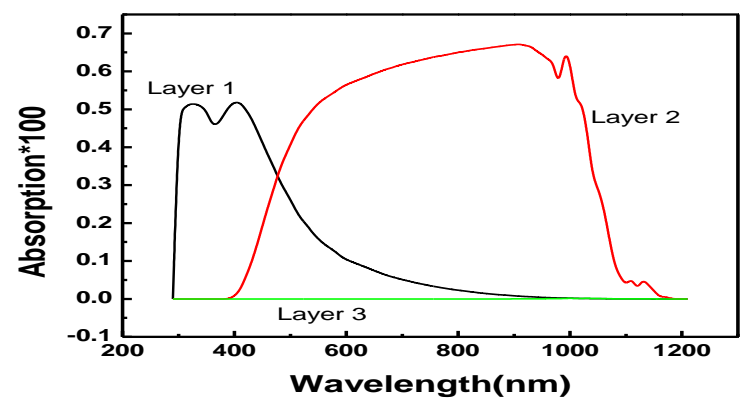

Fig.3: Absorbance curve for different wavelengths

The Fig. 4 indicates the simulated I-V curve of n-type solar cell. The open circuit voltage $\left(\mathrm{V}_{\mathrm{oc}}\right)$ is the potential difference that is developed between the two terminals of the cell when external load resistance is large and the short circuit current $\left(\mathrm{I}_{\mathrm{sc}}\right)$ is the current when load resistance is zero. The $\mathrm{I}_{\mathrm{sc}}$ and $\mathrm{V}_{\mathrm{oc}}$ are the key parameters for efficiency of the solar cell.

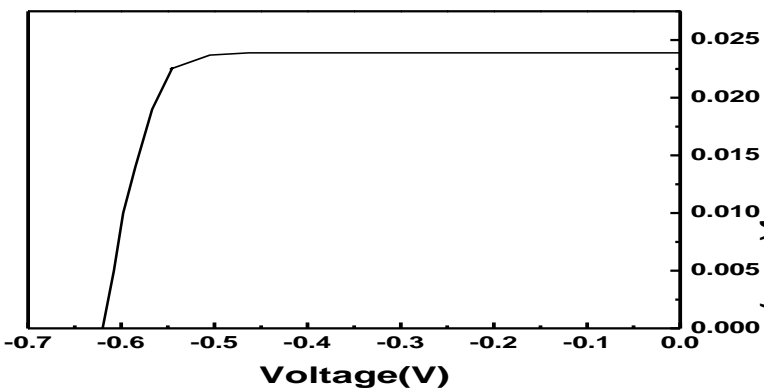

Fig.4.Current Vs Voltage curve of the Solar Cell

For increasing efficiency, the antireflection coating $\mathrm{SiN}_{\mathrm{x}}$ is usually used on both $\mathrm{p}$ - type and n-type solar cell. Because of the high positive charge density of $\mathrm{SiN}_{\mathrm{x}}$ film serves a poor performance for $\mathrm{n}$-type solar cell than p-type [6]. The comparative result is shown in table 2.

Table2: Variation of efficiency in p- type and n- type Solar cell after giving $\mathrm{SiN}_{\mathrm{x}}$ ARC

\begin{tabular}{|l|l|l|}
\hline \multirow{2}{*}{ Description of ARC } & \multicolumn{2}{|c|}{ Conversion Efficiency } \\
\hline $\begin{array}{l}\text { PECVD }\left(\operatorname{SiN}_{\mathrm{x}}\right) \text { ARC coating } \\
\text { thickness }=75 \mathrm{~nm} \text {, refractive index }=2.1\end{array}$ & $\mathrm{~N}$ type & P type \\
\cline { 2 - 3 } & $17.2 \%$ & $18.2 \%$ \\
\hline
\end{tabular}


Comparative simulation study between n- type and p- type Silicon Solar Cells and the variation of

Surface recombination velocity plays an important role on the variation of short circuit current and open circuit voltage. Higher recombination rates at the top surface give a detrimental impact on short circuit current. Top layer surface recombination can be reduced by decreasing the dangling bonds of Silicon by using a passivation layer. It has already been reported that due to the presence of oxide layer $\mathrm{Al}_{2} \mathrm{O}_{3}$ serves as a good passivation layer for $\mathrm{n}$ type solar cell [5-7]. So in this paper $\mathrm{Al}_{2} \mathrm{O}_{3}$ is used to neutralize these dangling bonds which lead to decrease the surface recombination velocity (SRV) and increases the minority carrier lifetime. Table 4 shows the simulation result after giving $\mathrm{Al}_{2} \mathrm{O}_{3}$ on the surface of $\mathrm{Si}$ and above which we apply $\mathrm{SiN}_{\mathrm{x}}$ AntiReflection coating [6]. The following result gives higher efficiency than the efficiency obtained in table 1 and 2. $\mathrm{Al}_{2} \mathrm{O}_{3} / \mathrm{SiN}_{\mathrm{x}}$ stack layer reduces the FSRV up to $10 \mathrm{~cm} / \mathrm{s}[6]$. But before that operation $\mathrm{SRV}$ we adjust $\mathrm{SiN}_{\mathrm{x}}$ and $\mathrm{Al}_{2} \mathrm{O}_{3}$ thickness for maximizing the efficiency[6].

The schematic structure of the $\mathrm{p}^{+} \mathrm{nn}^{+}$crystalline silicon (c-Si) solar cell is used during simulation (AFORS HET) with $\mathrm{SiN}_{\mathrm{x}} \mathrm{ARC}$ and $\mathrm{Al}_{2} \mathrm{O}_{3}$ passivated layer as shown in Fig.5

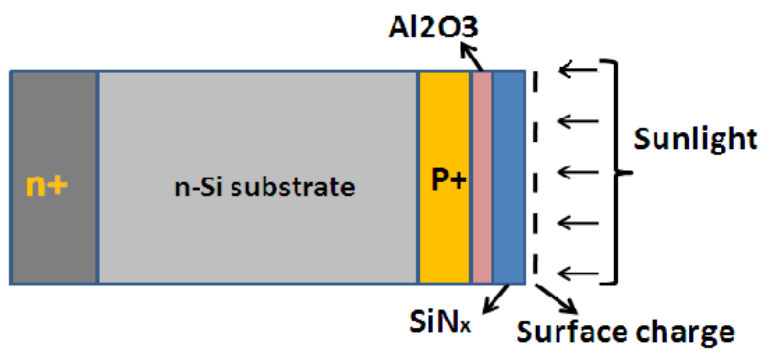

Fig.5 Schematic diagram for $\mathrm{p}^{+} \mathrm{nn}^{+}$with $\mathrm{SiN}_{\mathrm{x}} \mathrm{ARC}$ and $\mathrm{Al}_{2} \mathrm{O}_{3}$ passivation layer

Table 3: Variation of efficiency with the variation of thickness with $\mathrm{Al}_{2} \mathrm{O}_{3}$ and $\mathrm{SiN}_{\mathrm{x}}$ AR coating

\begin{tabular}{|c|c|c|}
\hline $\mathrm{Al}_{2} \mathrm{O}_{3}$ thickness $(\mathrm{nm})$ & SiN $_{\mathrm{x}}$ thickness $(\mathrm{nm})$ & Efficiency $((\%)$ \\
\hline 60 & 70 & 14.06 \\
\hline 50 & 70 & 14.9 \\
\hline 40 & 70 & 15.81 \\
\hline 30 & 70 & 16.98 \\
\hline 20 & 70 & 17.85 \\
\hline 10 & 70 & 18.41 \\
\hline 10 & 65 & 18.59 \\
\hline 10 & 50 & 18.38 \\
\hline 10 & 40 & 17.67 \\
\hline
\end{tabular}

Table 4: Variation of efficiency with the variation surface recombination velocity with $\mathrm{Al}_{2} \mathrm{O}_{3}$ and $\mathrm{SiN}_{\mathrm{x}} \mathrm{AR}$ Coating

\begin{tabular}{|l|l|l|}
\hline $\begin{array}{l}\text { Front Surface Recombination } \\
\text { Velocity }\left(\mathrm{cm} / \mathrm{s}^{2}\right)\end{array}$ & $\begin{array}{l}\text { Rear surface Recombination } \\
\text { Velocity }\left(\mathrm{cm} / \mathrm{s}^{2}\right)\end{array}$ & $\begin{array}{l}\text { Efficiency } \\
(\%)\end{array}$ \\
\hline 1000 & 10000 & 19.94 \\
\hline 100 & 10000 & 19.97 \\
\hline 10 & 10000 & 20.12 \\
\hline 10 & 1000 & 20.28 \\
\hline 10 & 100 & 20.3 \\
\hline 10 & 10 & 20.15 \\
\hline 8 & 100 & 20.15 \\
\hline 4 & 100 & 20.15 \\
\hline
\end{tabular}

The final simulation analysis after development of $\mathrm{Al}_{2} \mathrm{O}_{3} / \mathrm{SiN}_{\mathrm{x}}$ film above the emitter layer of $\mathrm{n}$-type cell shows efficiency raises up to $7 \%$ than the without $\mathrm{Al}_{2} \mathrm{O}_{3} / \mathrm{SiN}_{\mathrm{x}}$ film on $\mathrm{n}$ type solar cell. The result is given below. 
Comparative simulation study between $\mathrm{n}$ - type and p- type Silicon Solar Cells and the variation of

Table 5: Variation of different parameters of N type Solar Cell

\begin{tabular}{|c|c|c|c|}
\hline Varying Parameters & Value & \multirow{2}{*}{$\begin{array}{l}\text { AFORS HET } \\
\text { simulation } \\
\text { result }\end{array}$} & \multirow{2}{*}{$\begin{array}{l}\text { PC1D simulation } \\
\text { result }\end{array}$} \\
\hline $\begin{array}{l}\text { Surface passivation layer } \\
\left(\mathrm{Al}_{2} \mathrm{O}_{3}\right) \text { thickness }\end{array}$ & $10 \mathrm{~nm}$ & & \\
\hline ARC coating thickness & $60 \mathrm{~nm}$ & \multirow{3}{*}{$\begin{array}{l}\text { Voc }=750.3 \mathrm{mV} \\
\mathrm{J}_{2} \mathrm{sc}=37.12 \mathrm{~A} / \mathrm{cm} \\
\mathrm{FF}=72.33 \%, \\
\eta=20.15 \%\end{array}$} & \multirow{3}{*}{$\begin{array}{l}\text { Voc }=676.2 \mathrm{mV} \\
, J s c=35.3 \mathrm{~A} / \mathrm{cm}^{2}, \\
\eta=20.13 \%\end{array}$} \\
\hline $\begin{array}{l}\text { Front } \quad \text { surface } \\
\text { recombination velocity }\end{array}$ & $10 \mathrm{~cm} / \mathrm{s}$ & & \\
\hline $\begin{array}{l}\text { Rear } \\
\text { recombination velocity }\end{array}$ & $100 \mathrm{~cm} / \mathrm{s}$ & & \\
\hline
\end{tabular}

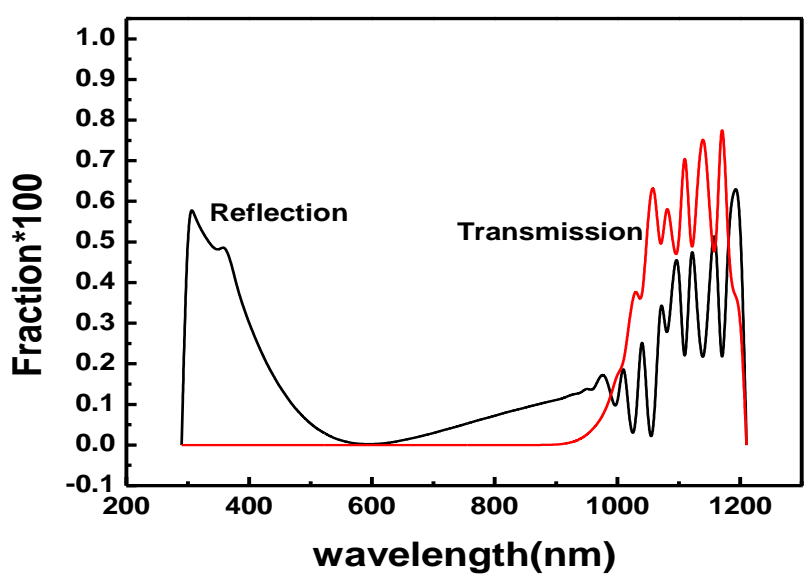

Fig.6 Reflectance and Transmittance curve for different

The reduction in reflection indicates the increase of absorption in bulk layer. We observed that the absorption is increases to $20 \%$ than the previous analysis as shown in Fig.7. The I-V characteristics graph as shown in Fig. 8 provides a higher short circuit current density than the initial one. This implies due to the reduction of reflection and increasing the absorption the rate of generation of carriers has been raised, which increases the efficiency up to $20.13 \%$. The simulation analysis shows standard reflection graph after giving $\mathrm{Al}_{2} \mathrm{O}_{3} / \mathrm{SiN}_{\mathrm{x}}$ stack layer, which is shown in Fig 6.

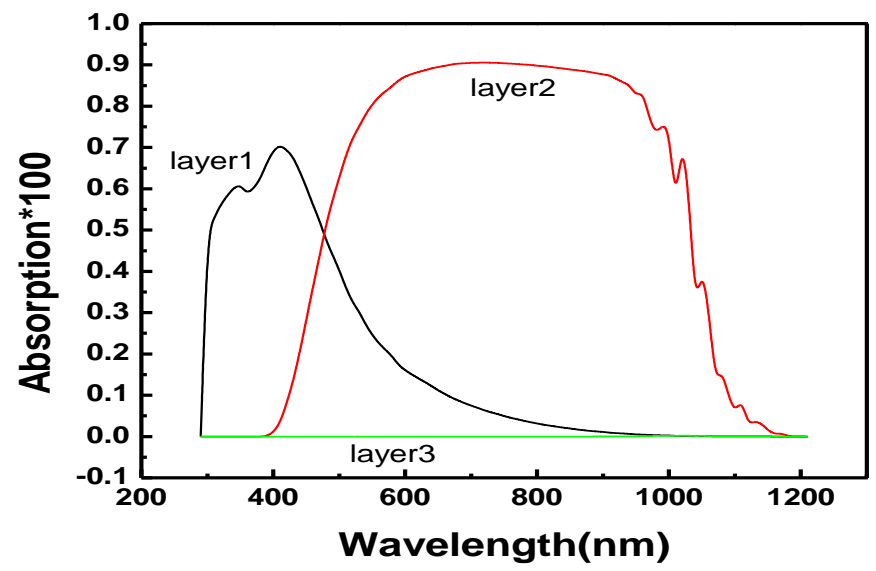

Fig.7 Absorbance curve for different wavelength 


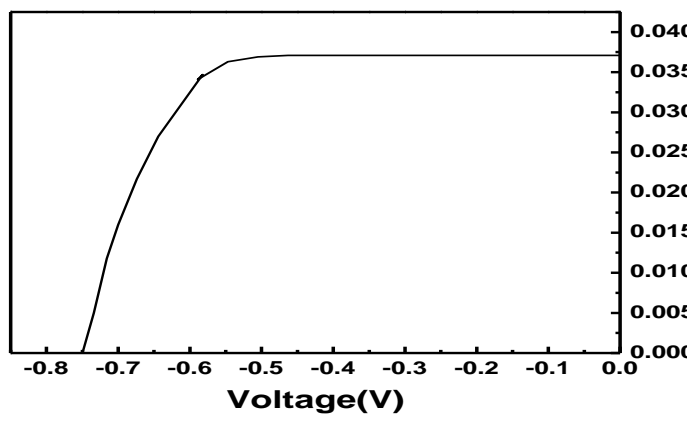

Fig.8 Current Vs Voltage curve of the Solar Cell

\section{II.II QUANTUM EFFICIENCY VARIATION OF N TYPE SOLAR CELL WITH FSRV}

The "quantum efficiency" (Q.E.) is the ratio of the number of carriers collected by the solar cell to the number of photons of a given energy incident on the solar cell. The quantum efficiency may be given either as a function of wavelength or as energy. If all photons of a certain wavelength are absorbed and the resulting minority carriers are collected, then the quantum efficiency at that particular wavelength is unity. It is measured in electrons per photon or amps per watt. There are two types of quantum efficiency is generally considered. External quantum efficiency (EQE) which is the ratio of the number of charge carriers collected by the solar cell to the number of photons of a given energy incident on the solar cell from outside and the another one is internal quantum efficiency (IQE). It indicates the ratio of the number of charge carriers collected by the solar cell to the number of photons of a given energy that shine on the solar cell from outside and are absorbed by the cell. So the surface recombination velocity makes a deep impact on the variations of IQE and EQE. Higher surface recombination velocity implies that the rate of generation of charge carriers in the Solar cell reduces. So the IQE and EQE both must also be decreased with the increasing of surface recombination velocity. The simulation of the variation between front surface recombination velocity and IQE or EQE has been done by using both type of simulator such as PC1D and AFORS HET. The results are shown in the Fig. 9, 10, 11 and 12 respectively.

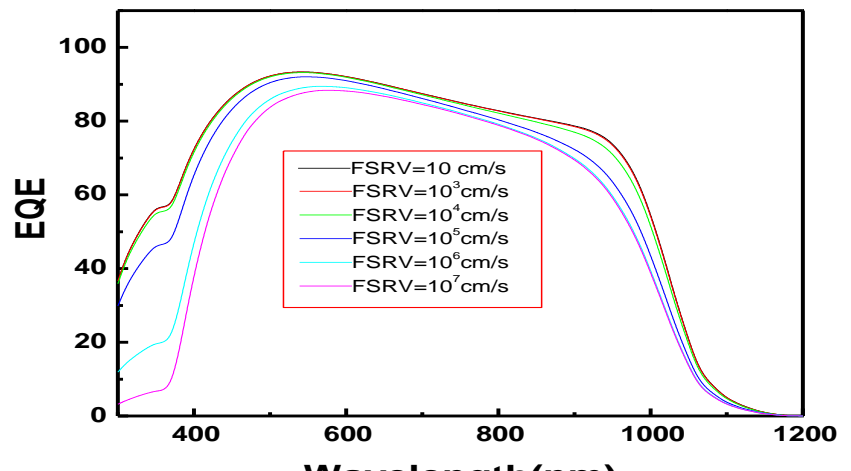

Fig9. Variation of EQE with different $\overline{\mathrm{FSR}}$ by using PC1D

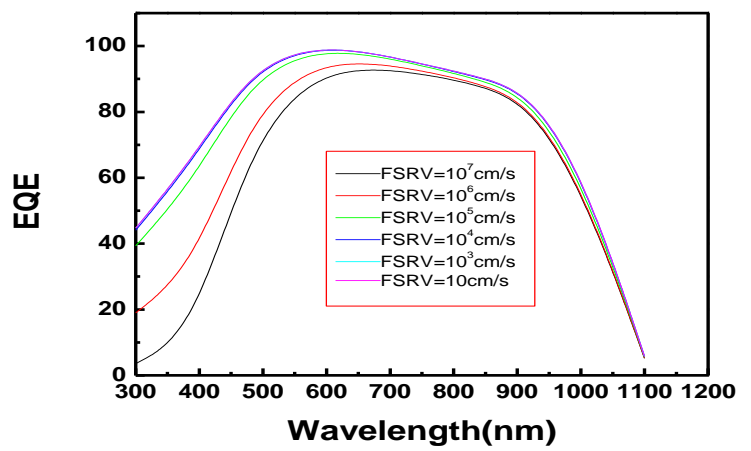

Fig10. Variation of EQE with different FSRV by using AFORS HET 
Fig.9 and Fig.10 shows the variation of EQE with different FSRV. Both of the graphs indicate that the $\mathrm{EQE}$ reduces with the increase of FSRV due to the loss of carriers. In a similar way IQE also decreases with the increasing of FSRV. These results are shown in Fig. 11 and Fig.12 respectively.

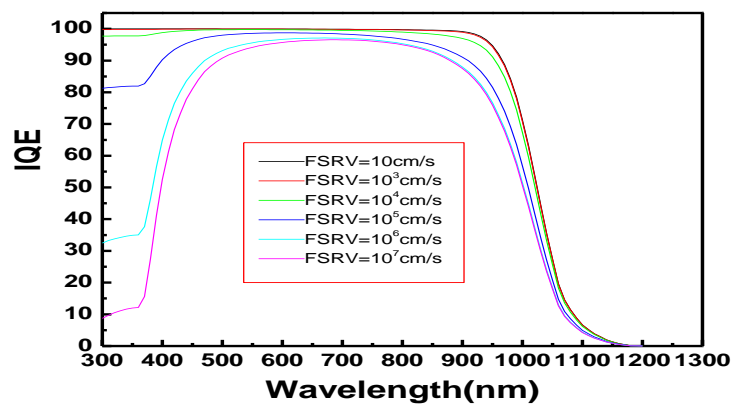

Fig11. Variation of IQE with different FSRV by using PC1D

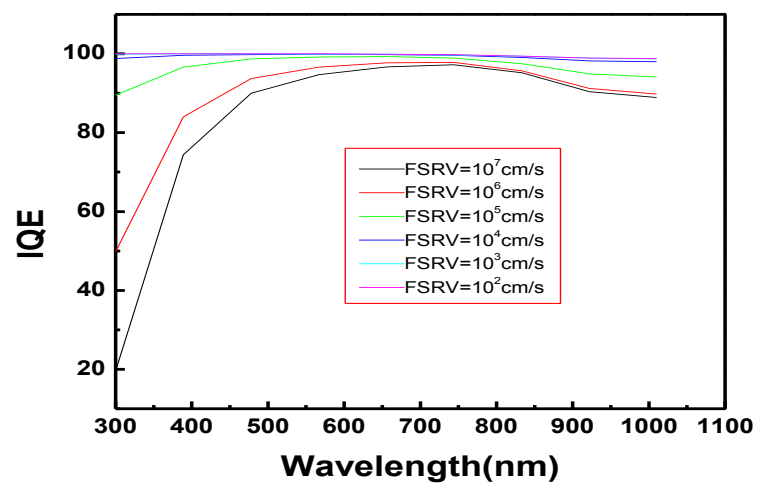

Fig12. Variation of IQE with different FSRV by using AFORS HET

\section{II.III SURFACE CHARGE DENSITY ROLE ON SOLAR CELL EFFICIENCY}

Now a different approach is performed by applying surface charge density at the front and rear surface of n-type Solar Cell [6]. Application of Surface charge density on the buffer layer $\mathrm{Al}_{2} \mathrm{O}_{3}$ enhances or reduces the recombination at the surface of the cell. This fact entirely depends upon the type of the polarity of the surface charge, doping of semiconductor layer and the type of buffer material. So positive and negative charge density has been imposed alternatively on the front surface of the cell and investigates the result. The effect of surface charge density is shown using PC1D simulation. For the simulations of Solar cell here FSRV $5000 \mathrm{~cm} / \mathrm{s}$, RSRV $100 \mathrm{~cm} / \mathrm{s}$ is taken It has been observed from PC1D simulation results as shown in Fig.13 and table-7 that efficiency of the $\mathrm{p}^{+} \mathrm{nn}^{+}$is increases with the presence -ve surface charge density on the front surface and maximum at $-6.88 \times 10^{12} \mathrm{~cm}^{2}$. This amount of -ve charge can give maximum efficiency $19.87 \% \mathrm{of}^{+} \mathrm{nn}^{+}$ crystalline silicon solar cell(c-Si). On the other hand the efficiency of the c-Si solar cell is decreases with increase of +ve surface charge density as indicated in the Fig.13 and table-7.

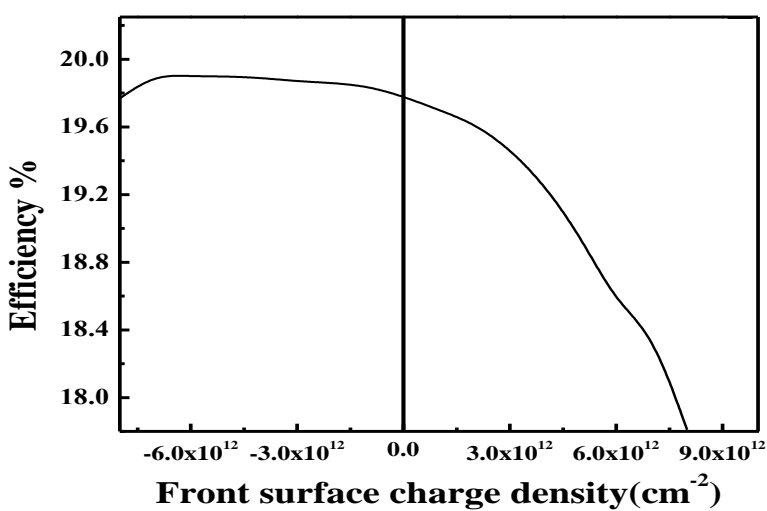

Fig.13 Variation of conversion efficiency with -ve and +ve front surface charge density 
Comparative simulation study between n- type and p- type Silicon Solar Cells and the variation of

Table7: Change of Efficiency with the variation of Surface charge at SRV $\mathrm{FSRV}=5000 \mathrm{~cm} / \mathrm{s}, \mathrm{RSRV}=100 \mathrm{~cm} / \mathrm{s}$

\begin{tabular}{|c|l|l|l|}
\hline $\begin{array}{l}\text { Surface } \\
\text { Charge } \\
(\mathrm{cm}-2)\end{array}$ & $\begin{array}{l}\text { Efficiency } \\
(\%)\end{array}$ & $\begin{array}{l}\text { Short circuit } \\
\text { current } \\
\text { density }\left(\mathrm{mA} / \mathrm{cm}^{2}\right)\end{array}$ & $\begin{array}{l}\text { Open circuit } \\
\text { voltage }(\mathrm{mV})\end{array}$ \\
\hline$-8 \mathrm{E} 12$ & 19.77 & 36.17 & -655.1 \\
\hline$-7 \mathrm{E} 12$ & 19.91 & 36.24 & -657.9 \\
\hline$-6 \mathrm{E} 12$ & 19.9 & 36.24 & -657.9 \\
\hline$-5 \mathrm{E} 12$ & 19.9 & 36.24 & -657.7 \\
\hline$-4 \mathrm{E} 12$ & 19.89 & 36.24 & -657.5 \\
\hline$-3 \mathrm{E} 12$ & 19.87 & 36.23 & -657.2 \\
\hline$-2 \mathrm{E} 12$ & 19.86 & 36.22 & -656.8 \\
\hline$-1 \mathrm{E} 12$ & 19.84 & 36.21 & -656.4 \\
\hline 0 & 19.78 & 36.18 & -655.3 \\
\hline $1 \mathrm{E} 12$ & 19.7 & 36.14 & -653.6 \\
\hline $2 \mathrm{E} 12$ & 19.62 & 36.08 & -651.8 \\
\hline $3 \mathrm{E} 12$ & 19.47 & 35.99 & -648.8 \\
\hline $4 \mathrm{E} 12$ & 19.25 & 35.84 & -644.7 \\
\hline $5 \mathrm{E} 12$ & 18.95 & 35.61 & -639.4 \\
\hline $6 \mathrm{E} 12$ & 18.56 & 35.27 & -633 \\
\hline $7 \mathrm{E} 12$ & 18.39 & 35.1 & -630.5 \\
\hline $8 \mathrm{E} 12$ & 17.81 & 34.47 & -622.3 \\
\hline
\end{tabular}

\section{CONCLUSION}

We have reported that the fabrication process of $n$-type solar cells based on surface passivation layer leads to a record efficiency of $20.1 \%$ for large area crystalline silicon solar cell, while the same process on p-type solar cell resulted in $18.2 \%$ efficiency. By improving the front surface passivation somewhat higher efficiencies can still be obtained on $\mathrm{n}$-type wafers by this process. High efficiencies may also be received on $\mathrm{n}$-type solar cell if the -ve surface charge is imposed on the c-Si solar cell front surface by thin layer of $\mathrm{Al}_{2} \mathrm{O}_{3}$ passivated layer. With proper optimization of front surface charges more efficiency will be envisioned.

\section{Acknowledgements}

The authors deeply acknowledge Meghnad Saha Institute of Technology, TIG provides the infrastructural support for carrying out research activity in this area. The authors also gratefully to acknowledge the DST, Govt. of India for financial support for carrying out solar cell related research activity.

\section{REFERENCES}

[1] A.Cuevas, M.J.Kerr, C.Samundsett, F.Ferraza, G.Cotelti, "Millisecond minority carrier lifetime in n-type multicrystalline silicon", Appl. Phys. Lett.,81(2002) 4952-4954.

[2] Arnab Das,Kyungsun Ryu,Ajeet Rohatgi,"20\% Efficient Screen-Printed n-type Solar Cells Using a Spin On source and Thermal Oxide/Silicon Nitride Passivation”, IEEE journal of Photovoltaic,Vol..1,No.-2,December(2011),Page-146-148.

[3] K Chandra Sahoo, Yiming Li, Edward Yi Chang, Men-Ku Lin, Jin-Hua Hung, " Reflectance of Sub-Wavelength Structure on Silicon Nitride For Solar Cell Application", Proceeding of IEEE Specialist Conferrence(2009),Page-123.

[4] I.Martin,R.Lovblom,R.Alcubilla,"High Efficiency Solar Cells Based on Inversion layer Emitters.",24 ${ }^{\text {th }}$ European Photovoltaic Solar Energy Conference, 21-25 ${ }^{\text {th }}$ September(2009),Hamberg,Germany,Page-1988.

[5] K.J.Weber,H.Jin,C.Zhang,N.Nursan,W.E Jellett,K.R.McIntosh,"Surface Passivation using dielectric films: How much charge is enough?",24 $4^{\text {th }}$ European Photovoltaic Solar Energy Conference, $21-25^{\text {th }}$ September(2009),Hamberg,Germany,Page- 534.

[6] Wu Dawei., JiaRui, Ding Wuchang,Chen Chen, Wu Deq,Chen Wei, Li Haofeng, YueHuihui, and Liu Xinyu. "Optimization of $\mathrm{Al}_{2} \mathrm{O}_{3} / \mathrm{SiNx}$ stacked antireflection structures for N-type surface passivated crystalline silicon solar cellsJournal of Semiconductors, " Vol. 32, No. 9 ,September(2011), Page-094008-1 to-094008-2.

[7] J.Benick,B.Hoex,G.Dingemans,W.M.MKessels,A.Richter,M.Hermle,S.W.Glunz, "High Efficiency N-type Silicon Solar Cells With Front Side Boron Emitter", $24^{\text {th }}$ European Photovoltaic Solar Energy Conference, Hamburg ,Germany, 21-25 ${ }^{\text {th }}$ September(2009),Page863.

[8] Gang He,Xiaoliang Wang,Masaharu Oshima,Yukihiro Shimogaki," Metalorganic Chemical Vapour Deposition of $\mathrm{Al}_{2} \mathrm{O}_{3}$ thin film from Dimethyl aluminiumhydride and $\mathrm{O}_{2}$ "Japanese Journal of Applied Physics,Vol-49(2010),Page-031502-4 